\title{
Holocene uplift and subsidence along an active tectonic margin southwestern Taiwan
}

\author{
Yue-Gau Chen*, Tsung-Kwei Liu \\ Department of Geology, National Taiwan University, 245 Choushan Road, Taipei 106-17, Taiwan, Republic of China
}

\begin{abstract}
Taiwan is located along a convergent plate boundary, where the Luzon Arc collides with the Eurasia continental margin. The Tainan Plain of southwestern Taiwan is incorporated into and deformed by a regional fold-and-thrust belt associated with this convergent plate margin. In this study we establish a tentative regional Holocene relative sea-level curve that allows us to analyze crustal uplift and subsidence rates of the Tainan Plain. The maximum Holocene uplift rates on the Tainan Plain occur on the Tainan Tableland and the Chungchou Terrace. These two areas have experienced long-term (Holocene) uplift rates of 5 and $7 \mathrm{~mm} / \mathrm{yr}$, respectively. The Tawan Lowland, located between these two areas, is subsiding at a long-term rate of about $1 \mathrm{~mm} / \mathrm{yr}$. Based on this pattern of the crustal movement, the Tainan Tableland is interpreted as a mud diapiric dome, and the Chungchou Terrace as the product of a blind thrust fault. The Holocene reference sea-level curve proposed in this study can be used to determine the pattern of crustal movements elsewhere in Taiwan. It also can suggest that the Holocene terrace development does not occur in area where the uplift rate exceeds $8 \mathrm{~mm} / \mathrm{yr}$, while late Holocene regression, the general trend around the western Pacific, is not recorded where the rate of subsidence is lower than $1 \mathrm{~mm} / \mathrm{yr}$. (C) 2000 Elsevier Science Ltd. All rights reserved.
\end{abstract}

\section{Introduction}

Taiwan is located along a convergent plate boundary between the Philippine Sea plate and the Eurasia continental plate (Fig. 1; Teng, 1990). The Tainan Plain of southwestern Taiwan (Fig. 2) therefore provides an opportunity to study uplift and subsidence rates in the outer part of a regionally active fold-and-thrust belt. Based on radiocarbon ages (Wu, 1990; Wu et al., 1992; Chen, 1993; Chen et al., 1994) and our relative sea-level curves for late Holocene (Chen and Liu, 1996), we measure rates of the crustal movement along a west-east cross-section (Fig. 2) of the Tainan Plain. The purpose of this study is to establish both rates and possible causes of crustal movement on this plate boundary.

Because compaction of thin, young, and sandy superficial deposits in the Tainan Plain is negligible when compared to rapid sea-level change and rapid crustal movement (deduced from Steckler and Watts,

\footnotetext{
* Correspondence author. Tel.: + 886-223630231X2672; fax: + 8862-2363-6095.

E-mail address: ygchen@ccms.ntu.edu.tw (Yue-Gau Chen).
}

1978, 1982), relative sea-level change recorded in the covering sedimentary deposits is resulted only from the two latter factors (Orford, 1987; Tooley, 1987). We establish absolute vertical crustal movements along southwestern Taiwan, by first-determined synchronous sea-level change in the western Pacific. This we achieve by combining the sea-level change curve of the Penghu Islands (Chen and Liu, 1996) with those from other adjacent areas of the Pacific region (Adey, 1978; Beaman et al., 1994; Chappell and Polach, 1991; Chao, 1984; Fujii et al., 1971; Geyh et al., 1979; Gibb, 1983, 1986; Huang et al., 1987; Katili and Tjia, 1969; Larcombe et al., 1995; Maeda et al., 1986; Nunn, 1990; Ota and Machida, 1987; Suggate, 1968; Sugimura et al., 1988; Thom, 1983). Then we construct a set of relative sea-level change curves for southwestern Taiwan to evaluate rates of local crustal movement during the Holocene (Fig. 5). Finally, we evaluate local uplift and subsidence in southwestern Taiwan by combining these sea-level curves with time-altitude data points sampled along a line across the Tainan Plain. (Fig. 5; Wu et al., 1992; Chen, 1993; Chen et al., 1994). Previous studies, including seismic stratigraphy, gravity, and aerial photography analyses (Hsieh, 1972; Sun, 1964), supposed the dual diapirism occurring under this area. However, our result of the crustal 


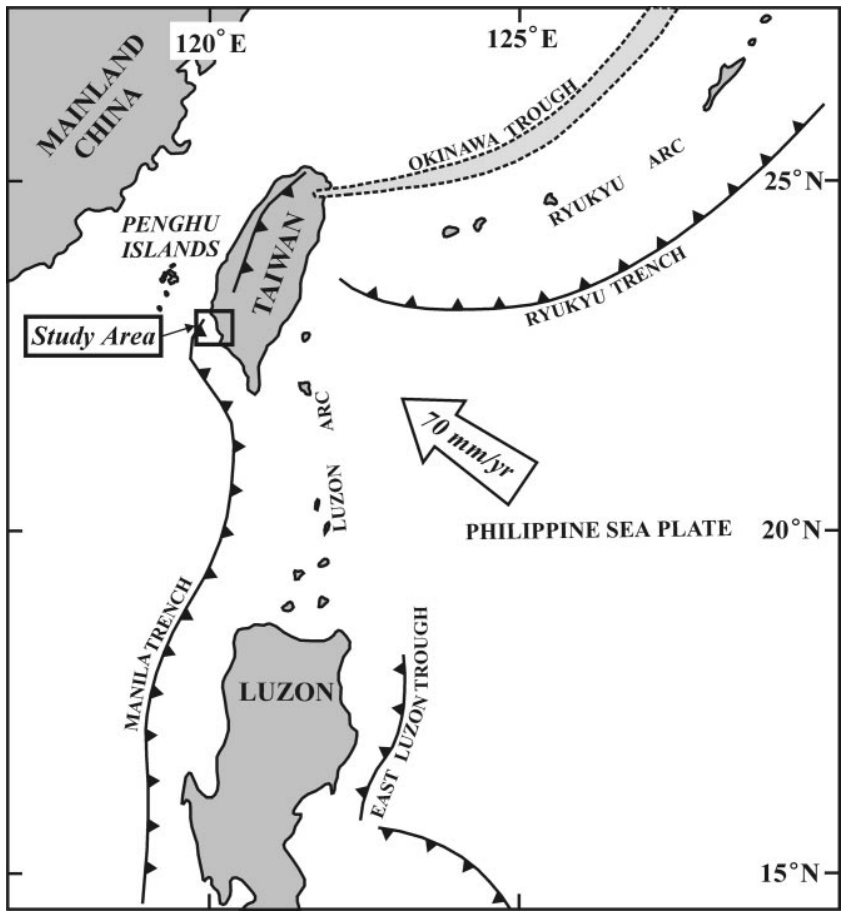

Fig. 1. Map showing the tectonic setting of Taiwan, which is at the junction of two arc-trench systems. Due to ongoing arc-continent collision, a fold-thrust wedge consisting of several mountain belts is being built westward. Modified from Page and Suppe (1981), Ho (1982) and Teng (1990).

movement during the Holocene indicates that only one of the proposed diapir is still active (Fig. 5; see text for discussion). We, hence, suggest that the eastern side of the Tainan Plain has been affected by front thrust of the fold-thrust belt situated in the east of the study area. In addition, the success in using a reference sea-level curve makes such a reference curve and a method could be applied to the other places, where the Holocene neotectoics has long been understood.

\section{Tectonic and geomorphic setting}

Taiwan is located on a convergent plate boundary (Fig. 1; Teng, 1990) where the Luzon Arc collides with the Eurasia continental margin. The main structural elements in Taiwan trend northeast with a northwestward vergence. The westernmost surface exposures of the foldand-thrust belt reach the boundary between the Foothills region and the Tainan Plain (Fig. 1). Suppe (1981) treated the westernmost exposed thrust fault as the thrust front in his interpretation of the mechanics of orogen development. Ho (1982) reported that the thrust front probably lies at the western boundary of the Foothills, but he also mentioned that it might extend westward beneath the coastal plain area. Two recent papers, based on interpretation of submarine seismic profiles, suggest that the

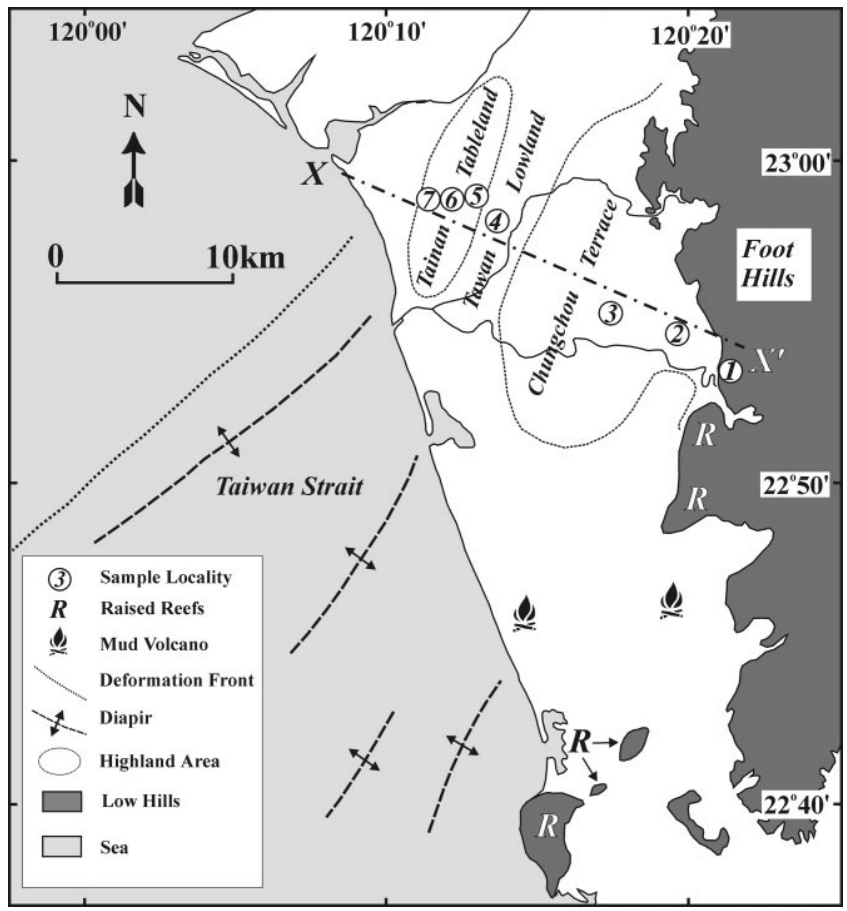

Fig. 2. Map showing geological and geomorphic features on the Tainan Plain (unshaded area). Seven sampling sites are located along the $X X^{\prime}$ traverse, which is perpendicular to the major structural trend.

deformation front of southwestern Taiwan extends into Taiwan Strait (Lundberg et al., 1991; Liu et al., 1997). This conclusion is deduced from attributing the observed antiform structures deforming the uppermost sedimentary deposits to mud diapirs that form in response to high pressure associated with thrust loading. Similar diapiric structures occur under the Tainan Plain (Hsieh, 1972), and locally control topography (Sun, 1964). By this interpretation, the Tainan Plain is located between the uplifted thrust belt and the active deformation front with abundant mud diapirism.

The Tainan Plain can be divided into three parallel geomorphic units of different altitudes (Fig. 2). These units are all covered by the Holocene coastal deposits less than $20 \mathrm{~m}$ thick over a basement high, and more than 70 $m$ thick over a basement low. On basement highs, i.e., the Tainan Tableland and Chungchou Terrace, we found the contacts between the covering strata and their underlain strata are the angular unconformities. In the basement low, so far no study has been done reaching the contact depth. Thus, the exact position of the basement is still unknown, whereas it should be deeper than $-50 \mathrm{~m}$ due to our core study. The radiocarbon ages show that the strata of the basement on the highs are all older than $50 \mathrm{ka}$; however, the covering strata are all younger than $35 \mathrm{ka}$ and mainly during Holocene. Thus, it is expected that this is the place where the Holocene local crustal 
activities can be understood if the synchronous depositional water-depth has been identified.

In the western part of the plain area lies the Tainan Tableland, which lies about $30 \mathrm{~m}$ above sea-level. Its western edge slopes gently seaward into the Taiwan Strait, whereas its eastern edge is a scarp bordering the Tawan Lowland. This scarp has been mapped as the Houchiali Fault based on aerial photographic study (Sun, 1964). The Tawan Lowland has an average altitude of about $6 \mathrm{~m}$ above sea-level. Its surface elevation increases eastward and gradually merges with the third unit - the Chungchou Terrace, a terrace with an elevation of $40 \mathrm{~m}$ in its inner part. The highest position of the Chungchou Terrace is located at its eastern boundary, where it merges with the Foothills, the westernmost part of the mountain range of Taiwan.

\section{Using reference Holocene sea-level curves to derive rates of uplift and subsidence}

Relative movement between the sea and the land consists of three main components: regional and local changes of sea-level, regional and local movements of the crust, and local compaction of unconsolidated deposits. Because of thin sandy Holocene deposits, the compaction effect in the Tainan Plain is probably negligible when compared to rapid sea-level change and rapid crustal movement (Steckler and Watts, 1978, 1982). The net movement of the crust cannot be resolved, however, if the Holocene sea-level changes are not well known. Because a sea-level curve for southwestern Taiwan has not been completed, we choose the sea-level change curve from the Penghu Islands (Chen, 1993; Chen and Liu, 1996), located $60 \mathrm{~km}$ east of our study area, as a starting reference. According to its R3 type and smooth characteristics (Fig. 3; Nakada, 1986; Chen and Liu, 1996), we are able to reconstruct the entire sea-level curve for our study area by adding two more critical data points, 6000 and 10,000 years ago (Fig. 3). For the first point we analyzed the R3 type sea-level curves of tectonically stable areas from the Pacific Ocean (Fig. 3) to deduce a value of $-1.3 \pm 2.7$ $(1 \sigma) \mathrm{m}$ as the paleo-sea-level. Unfortunately, there are not enough R3 curves for understanding the paleo-sea-level prior to 6000 years ago. Therefore, in deriving the second point at 10,000 $\mathrm{yr}$ ago, all the R1-R3 curves from the Pacific region were used instead (Fig. 3). These allowed us to calculate a value of $-30 \pm 6(1 \sigma) \mathrm{m}$ as another paleo-sea-level. Based on the above approach, we are able to extend the late Holocene sea-level change curve from Penghu to $10,000 \mathrm{yr}$ ago by smoothly connecting these two points. This results in a complete Holocene reference sea-level curve (Fig. 3 and sea-level marked by $0 \mathrm{~mm} / \mathrm{yr}$ in Fig. 5).

On the basis of the reference Holocene sea-level curve derived above, we further obtain a series of relative sea-

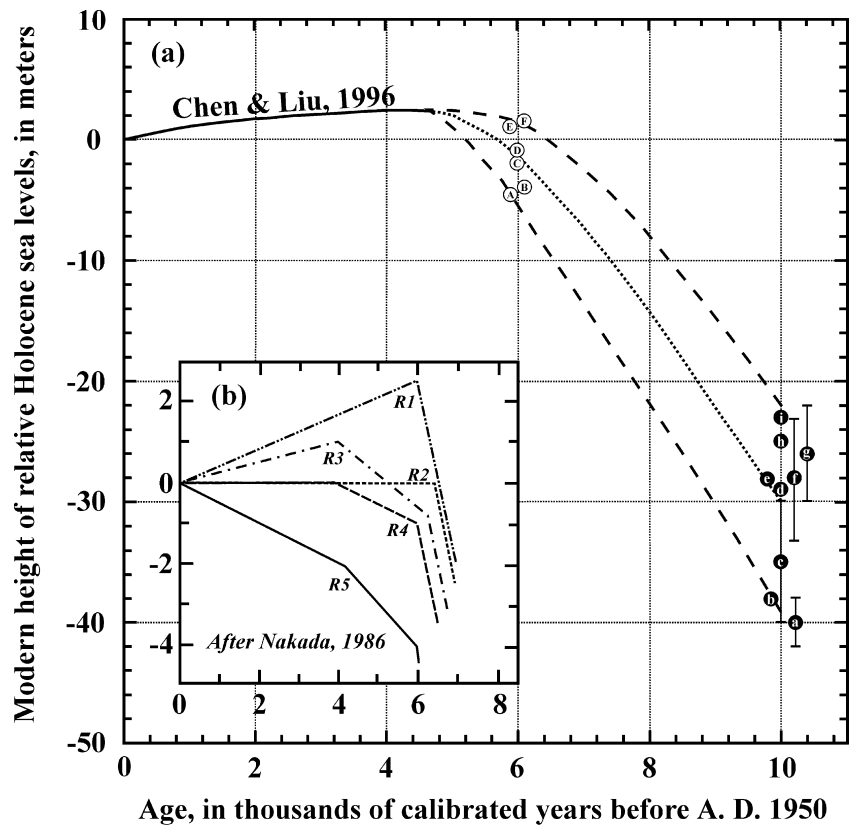

Fig. 3. (a) Reference Holocene sea-level change curve is derived by extending the curve of the Penghu Islands (Chen and Liu, 1996) smoothly drawing through two critical points (6000 and 10,000 years ago) which are from averaging the curves of other places around the Pacific. For the younger point, only R3 type curves are chosen (Nakada, 1986; see figure in left corner) and the value of $-1.3 \pm 2.7$ $(1 \sigma) \mathrm{m}$ is derived. Another point of $-30 \pm 6(1 \sigma) \mathrm{m}$ below the sea-level of present day can be determined, but all the R1-R3 type curves are the contributors. Two dash lines represent the uncertainty of our reference curve with $1 \sigma$ standard deviation. (b) Categorized types of Holocene sea-level curves (Nakada, 1986). The changing characteristics of the sea-level curve of Taiwan Strait matches the R3 type. Perpendicular bars represent the uncertainties that reported in the references. Note: A: Sugimura et al., 1988; B: Nunn, 1990; C: Adey, 1978; D: Suggate, 1968; E: Beaman et al., 1994; F: Geyh et al., 1979; a: Chappell and Polach, 1991; b: Geyh et al., 1979; c: Ota and Machida, 1987; d: Huang et al., 1987; e: Chao, 1984; f: Thom, 1983; g: Larcombe et al., 1995; h: Gibb, 1983, 1986; i: Adey, 1978.

level curves for the Tainan Plain by applying rates of tectonic uplift and subsidence of +8 to $-3 \mathrm{~mm} / \mathrm{yr}$ to the reference curves (Fig. 5). The curve marked $0 \mathrm{~mm} / \mathrm{yr}$ in Fig. 5 represents a place which underwent null vertical crustal movement during Holocene. In other words, it is the original reference curve integrated in Fig. 3. The other curves are derived from simply integrating the uplift and subsidence rate over time to this original reference curve. When we already have had such a set of curves in an age-height figure, the apparent net rate of uplift or subsidence then can be determined for each sampling locality by plotting on dated sample points (Fig. 5).

\section{Holocene coastal deposits and radiocarbon ages}

In the Tainan Plain almost all the Holocene deposits, named the Tainan Formation (Lin, 1969; Hashimoto, 
1972), are characterized by sedimentary structures representing coastal marine environments $(\mathrm{Wu}, 1990 ; \mathrm{Wu}$ et al., 1992; Chen, 1993). In sand-rich units, plane bed and large-scale trough cross-stratification are the dominant sedimentary structures. Burrow-type trace and mollusc fossils derived from neighboring marine environments (i.e., shallow marine and lagoon) are common. In mud-rich units, flaser and lenticular sand structures are frequent and abundant driftwood occurs. Also found in the mud-rich deposits are in situ molluscs and rhizomes. The thickness of the Tainan Formation varies across the
Tainan Plain. It is more than $100 \mathrm{~m}$ thick upon a structural low (Chang, 1977), whereas less than $20 \mathrm{~m}$ thick on the basement highs (Lin, 1971). Based on subsurface data, at the basement high area the raised-up geomorphic surface is underlain by an anticline (Hsieh, 1972; Fig. 4).

Four driftwoods and eight mollusc samples were collected for ${ }^{14} \mathrm{C}$ dating from the coastal sediments described in Fig. 4 (Table 1). The observed altitude of these samples is accurate to $\pm 0.2 \mathrm{~m}$ due to uncertainties caused from leveling and sampling. This error is small when compared to the error in tide levels, which is $2 \mathrm{~m}$ on

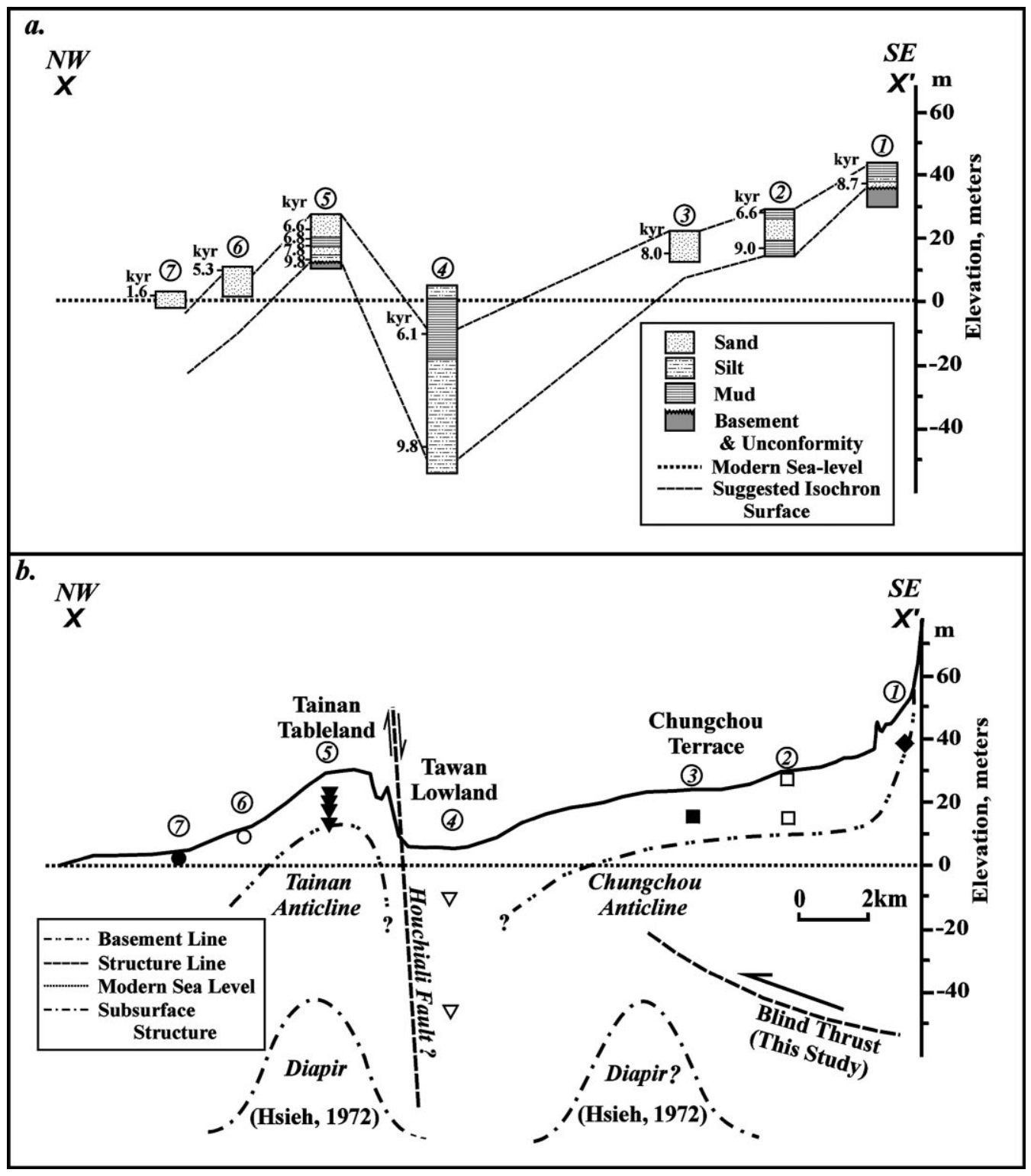

Fig. 4. a. Cross section $X-X^{\prime}$ (locality see Fig. 2) showing the column sections and, their modern heights. Circled numbers are our study sites. Vertical altitude scale and thickness scale of the column section are exaggerated 8 and 11 times, respectively. Age data attached on the left side of the column sections are calculated mid-points of calibrated ${ }^{14} \mathrm{C}$ age range. Dot line represents the modern sea-level. Dash lines connect estimated synchronous depositional surface: upper one for $6 \mathrm{ka}$ and lower one for $10 \mathrm{ka}$. In this figure, site 4 is obviously the depo-center along the cross section. $\mathrm{b}$. The same cross section $X-X^{\prime}$ but showing the topography, subsurface data, and mechanism for crustal movement suggested by previous and this study. Symbols as in Fig. 2, show locality elevation projected onto the line of cross section. 
Table 1

${ }^{14} \mathrm{C}$ ages from the Tainan area

\begin{tabular}{|c|c|c|c|c|c|c|}
\hline Locality & Longitude/Latitude & Elevation (m) & Age $\left({ }^{14} \mathrm{C} \text { yr B.P. }\right)^{\mathrm{a}}$ & $\begin{array}{l}\text { Calibrated Age } \\
{\text { (cal yr B.P. })^{\mathrm{b}}}^{\text {a }}\end{array}$ & Sample Type ${ }^{\mathrm{c}}$ & $\begin{array}{l}\text { Lab. }{ }^{\mathrm{d}} \text { and } \\
\text { (Reference }^{\mathrm{e}} \text { ) }\end{array}$ \\
\hline Tainan Tableland & $120^{\circ} 10^{\prime} 59^{\prime \prime} / 22^{\circ} 58^{\prime} 58^{\prime \prime}$ & 2.0 & $1710 \pm 40$ & $1530-1710$ & Molluscs (As, Pr) & NTU-1214 (A) \\
\hline Tainan Tableland & $120^{\circ} 14^{\prime} 24^{\prime \prime} / 23^{\circ} 00^{\prime} 01^{\prime \prime}$ & 22.6 & $5840 \pm 50$ & $6500-6770$ & Driftwood & NTU-1147 (A) \\
\hline Tainan Tableland & $120^{\circ} 14^{\prime} 24^{\prime \prime} / 23^{\circ} 00^{\prime} 01^{\prime \prime}$ & 20.3 & $5930 \pm 50$ & $6660-6880$ & Driftwood & NTU-1149 (A) \\
\hline Tainan Tableland & $120^{\circ} 14^{\prime} 24^{\prime \prime} / 23^{\circ} 00^{\prime} 01^{\prime \prime}$ & 17.7 & $6950 \pm 150$ & $7480-8050$ & Driftwood & NTU-1153 (A) \\
\hline Tawan Lowland & $120^{\circ} 15^{\prime} 00^{\prime \prime} / 22^{\circ} 58^{\prime} 11^{\prime \prime}$ & -46.0 & $8850 \pm 80$ & $9580-9990$ & Molluscs (Mi, Bz) & NTU-1180 (B) \\
\hline Chungchou Terrace & $120^{\circ} 19^{\prime} 41^{\prime \prime} / 22^{\circ} 56^{\prime} 27^{\prime \prime}$ & 15.0 & $7250 \pm 100$ & $7830-8180$ & Molluscs (Ad) & NZA2341 (B) \\
\hline Chungchou Terrace & $120^{\circ} 19^{\prime} 10^{\prime \prime} / 22^{\circ} 54^{\prime} 43^{\prime \prime}$ & 27.5 & $5840 \pm 50$ & $6500-6770$ & Molluscs (As) & NTU-1194 (B) \\
\hline Chungchou Terrace & $120^{\circ} 19^{\prime} 10^{\prime \prime} / 22^{\circ} 54^{\prime} 43^{\prime \prime}$ & 15.5 & $8110 \pm 50$ & $8760-9210$ & Driftwood & NTU-1447 (B) \\
\hline Low Hills & $120^{\circ} 20^{\prime} 54^{\prime \prime} / 22^{\circ} 53^{\prime} 37^{\prime \prime}$ & 37.5 & $7900 \pm 50$ & $8510-8950$ & Molluscs (Ag, Pr) & NTU-1465 (B) \\
\hline
\end{tabular}

${ }^{a}$ All the conventional ages were calculated using the ${ }^{14} \mathrm{C}$ half-life of $5568 \mathrm{yr}$, and were corrected for mass-fractionation of carbon isotopes by normalizing the $\delta^{13} \mathrm{C}$ values of the samples to $-25 \%$ o relative to PDB, an international standard. Carbonate samples were all checked by X-ray diffraction analysis; all samples contain $>95 \%$ aragonite.

${ }^{\mathrm{b}}$ Age data were calibrated according to Stuiver and Reimer (1993). We chose dataset \# 1 and an error multiplier of one $(k=1)$. The calibrated age ranges represent two standard deviations.

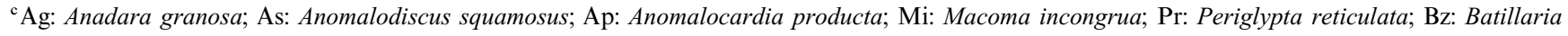
zonalis

${ }^{\mathrm{d} N T U}$ : The ${ }^{14} \mathrm{C}$ dating laboratory of the Precision Instrument Development Center, National Science Council, Republic of China, located in the Department of Geology, National Taiwan University. Teledyne: The ${ }^{14} \mathrm{C}$ dating laboratory located in New Jersey, United States of America. NZA: The AMS ${ }^{14} \mathrm{C}$ dating laboratory located in Institute of Geological and Nuclear Science, New Zealand.

${ }^{\mathrm{e}} \mathrm{A}$ : Wu et al., 1992; B: Chen et al., 1994.

an average and the major error source in this study. The mollusc shell samples were all checked by X-ray diffraction analysis to assure their purity. Broken or incomplete mollusc shells were not analyzed to minimize the possibility of dating reworked material. The molluscs we analyzed lived only in lagoons, we did not apply an additional marine reservior correction before calibrating the shell ages (Pirazzoli et al., 1987; Pirazzoli and Montaggioni, 1988). Both driftwood and mollusc shell samples were calibrated with the same calibration curve (Stuiver and Reimer, 1993; Table 1).

\section{Differential crustal movement rate}

A plot of elevations and measured stratigraphic sections at seven localities along cross section $X-X^{\prime}$ (Figs. 2 and 4) shows that different geomorphic units of the Tainan Plain have undergone different styles of crustal movement. The data show a subsiding area, the Tawan Lowland, and two areas that have been uplifted, the Tainan Tableland and Chungchou Terrace. To measure the rates of local crustal movement, sedimentary environments with a known relation to former sea-level must be identified. The best environments are beach face and intertidal deposits; we estimate an uncertainty of only $\pm 2 \mathrm{~m}$ in altitude for these types of deposits according to the modern tidal range, which is generally lower than $2 \mathrm{~m}$.

\subsection{Chungchou Terrace}

The beach face sand and intertidal mud in the stratigraphic section of the easternmost site (no. 1 in Fig. 4) formed near sea-level. The shell sample with a calibrated age of 8510-8950 cal. yrBP dates this sea-level position. The second site (no. 2 in Fig. 4), contains a beach face sand embraced between two muddy layers from which two dates were obtained. The upper muddy layer contains intertidal sedimentary structures, such as flaser and lenticular sand, thus representing a paleo-sea-level position. The lower mud unit has a massive structure with numerous driftwood fragments and shells of Macoma incongrua, a typical lagoonal and intertidal mollusc. Thus, the lower mud was deposited near sea-level. Only beach face sandy deposits, identified by the very flat, extended plane bed and the paleo-topography, are found in the third site; therefore, the paleo sea-level position of the third site can also be defined, because beach deposits are usually formed within tide interval. When plotted on our model of relative sea-level curves, the three sea-level points on the Chungchou Terrace give long-term uplift rates of about $4-7 \mathrm{~mm} / \mathrm{yr}$ (Fig. 4).

\subsection{Tawan Lowland}

A $70 \mathrm{~m}$ long core was drilled at the lowest position in the Tawan Lowland without reaching bedrock, the tilted Pleistocene strata found below the Holocene deposits at 
the Tainan Tableland and Chungchou Terrace. Two shell samples were ${ }^{14} \mathrm{C}$ dated from -10.3 to $-46.0 \mathrm{~m}$. For the purpose of understanding the detailed sedimentary environment, the morphology-composition analysis (Murry, 1973; Loeblich and Tappan, 1964) was conducted, based on assemblages of the benthic foraminiferids, the deposits of the upper $60 \mathrm{~m}$ of the core formed in a hypersaline lagoon except for the superficial $4 \mathrm{~m}$ (Chen, 1993; Chen et al., 1994). Modern analogs of such an environment suggest that the water depth was less than $6 \mathrm{~m}$. If so, a subsidence rate of $1 \mathrm{~mm} / \mathrm{yr}$ can be approached (Fig. 5).

\subsection{Tainan Tableland}

The two study sites from the western part of the Tainan Tableland both expose sandy beach face deposits (Fig. 3, site nos. 6 and 7). Two ${ }^{14} \mathrm{C}$ ages on shells give long-term uplift rates of about 0 to $2 \mathrm{~mm} / \mathrm{yr}$. At site no. 5 a 13-m-deep foundation excavation on the top of the Tainan Tableland provided an opportunity for sequential sampling. The upper sandy part consists of barrier island, which is mainly a tidal channel deposit and formed in the Holocene transgression (Wu, 1990; Wu et al., 1992). On the other hand, the lower muddy part of this sequence was deposited in a hypersaline lagoon $(\mathrm{Wu}$, 1990). Based on similar modern tidal channels ( $\mathrm{Wu}$, 1990), the maxium water depth is about $6 \mathrm{~m}$. Although these four sea-level points plotted on a relative sea-level curve representing uplift rate of $4 \mathrm{~mm} / \mathrm{yr}$ (Fig. 4); the water depth correction implies a higher rate of about $5 \mathrm{~mm} / \mathrm{yr}$.

\section{Differential crustal movement in the Tainan area}

Diagnosing the site no. 5, where we have the most age determinations and the longest time span, it can be found four data points nearly falling along the modeled relative sea-level curve. It implies that the model is a good approximation of sea-level rise on the Tainan Plain. Due to little gravity anomaly along Taiwan Strait (Yen et al., 1995) and lack of anomalous heat flow beneath it (Gong, 1997), we also suggest that the curve may be applicable to the western coast of Taiwan due to its restricted size. As we have known, the Taiwan Island is a tectonically active region, the reference sea-level is believed to be widely applicable in this area for studies of Holocene neotectonics. Since the reference sea-level is a general average of the tectonically stable areas around Pacific region, it might be valid when it is applied to the Pacific. However, outside of western Taiwan, using this reference sea-level curve must be cautious due to the local tectonism.

As far as we know, a marine terrace develops in a relatively uplifting place and during at least a transgression-regression cycle (Woods, 1980; Kern, 1977). If we

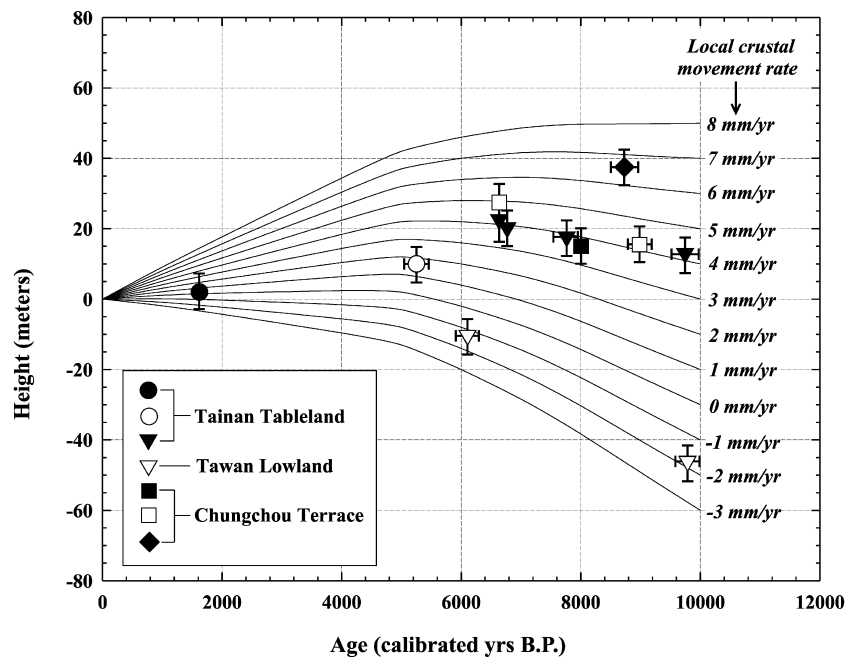

Fig. 5. Curves represent the relative sea-level change at the places undergoing specified rates of crustal movement during the Holocene. Symbols are used as in Figs. 2 and 4. Horizontal error bars show the total range of calibrated radiocarbon ages if the range is larger than the symbol size. Vertical error bars show the maximum uncertainties for height, which are $12 \mathrm{~m}$ or so due to the modern water depth of the similar environment. By reading relative position of the symbols, the Holocene tectonic activities of each sampling site can be approximately read out.

regard the Tainan Tableland and the Chungchou Terrace as having the same forming mechanism as marine terrace, such transgression-regression cycle must be experienced. Although there was a Holocene transgression-regression cycle generally happened in the western Pacific, the trend of the curves in Fig. 5 suggests that if the uplift rate is more than $8 \mathrm{~mm} / \mathrm{yr}$ sea-level has never been a rising trend. Thus, the Holocene marine strata would be hard to develop on the Tainan Plain. Consequently, the Holocene transgression-regression cycle has little chance to be detected. On the other hand, at a place that underwent a subsidence rate of more than $1 \mathrm{~mm} / \mathrm{yr}$, the late Holocene regression will not be found. In short, a place inundated prior to the Holocene would be still submerged (Lajoie, 1986). However, this latter case need not always exist, because rapid sedimentation may often exceed the rate of sea-level rise and cause shoreline progradation. This deposition-induced regression sometimes causes us to mistakenly interpret crust uplift and underestimate the local subsidence rate. Therefore, establishing the condition accompanying sediment deposition is very important in this type of study. For example, the Tawan Lowland in this study should still be inundated today, given its subsidence rate; however, in reality, the fluvial sediment supply makes it emerge faster than expected. The top $4 \mathrm{~m}$ of fluvial deposits found in the Tawan Lowland (Fig. 4) is the best support for the sedimentation-induced emergence.

The cross section of the Tainan area demonstrates that the uplift rate is very low along the western coast and 
increases eastward to a peak on the top of the Tainan Tableland. Beyond the peak, the rate drops down in the Tawan Lowland, and it increases again when reaching the Chungchou Terrace. The uplift rates derived from the Chungchou Tableland, in the same way, show an eastward increase into the Foothills. Although the average uplift rate in our study area is consistent with that reported for marine terraces on the Pacific side of Taiwan (Ota, 1986), these rates vary significantly across the Tainan Plain. The variation is the result of subsurface structural movement (Hsieh, 1972; Chen, 1993) as is true in other cases (Yeats, 1986; Figs. 5-13 and 5-15 in Carver and McCalpin, 1996). However, our average rate is quite high compared with these studies and may arise from a different style or scale of structural movement. Due to a lack of monitoring data, we can neither categorize the type, seismic or aseismic (Nelson and Manley, 1992), nor the moving behavior, variable or uniform slip model (McCalpin, 1996). Instead, we simply discuss the possible mechanism, which causes the differential movements in Tainan Plain.

Two underlying gravity anomalies have been reported beneath the topographic highs of the Tainan Tableland and Chungchou Terrace (Hsieh, 1972), but seismic data are available only beneath the Tainan Tableland. Two exploratory test wells support the idea of subsurface folds beneath these anomalies and probably both of the anticlines formed by diapirism (Hsieh, 1972). Marine seismic profiling studies (Lundberg et al., 1991; Liu et al., 1997) also show that the Tainan Tableland and Chungchou Terrace are on northwest-oriented structural trends formed by mud diapirism (Fig. 2). Based on these previous studies and our data, it can be suggested that the Tainan Tableland has been probably doming up by diapirism. Its asymmetrical shape is caused by both of seaward progradational deposition on the western flank and fluvial erosion on the eastern flank. For the Chungchou Terrace, however, the uplift rate increases eastward. Therefore, we suggest that diapirism is not the major mechanism for uplift of the Chungchou Terrace. Instead, it is possible that a blind thrust (Rich, 1934; Suppe, 1983) is developing beneath the terrace. This interpretation is also consistent with the gravity anomaly (Hsieh, 1972). As a result, the differential crustal movement rates observed in the Tainan area are mainly attributable to the mud diapirism for the Tainan Tableland and blind thrust faulting for the Chungchou Terrace.

\section{Conclusions}

Two Holocene uplifted geomorphic units, i.e., the Tainan Tableland and the Chungchou Terrace, demonstrate maximum uplift rates of about 5 and $7 \mathrm{~mm} / \mathrm{yr}$, respectively, and both show an eastward increase in uplift rates. The Tawan Lowland located between these two highlands has subsided at a rate of about $1 \mathrm{~mm} / \mathrm{yr}$. The mechanism of differential uplift across the Tainan Plain is interpreted to be the product of doming related to mud diapirism beneath the Tainan Tableland and blind thrust faulting beneath the Chungchou Terrace. The Holocene reference sea-level curve used in this study is believed to be highly applicable in determining the local crustal movement rate in western Taiwan, but we precaution the application to other places due to the possibility of different local tectonism.

\section{Acknowledgements}

We thank Prof. Y. Wang and Kenneth Ridgway for their critical comments and help in polishing the draft. Also, we thank Dr. Meigs and Dr. Knuepfer for their valuable suggestions and comments. This study is supported by National Science Council, Republic of China under grant numbers of NSC79-0202-M002-12 NSC800202-M002-01 and NSC81-0202-M002-01.

\section{References}

Adey, W., 1978. Coral reef morphogenesis: a multi-dimensional model. Science 202, 831-837.

Beaman, R., Larcombe, P., Carter, R.M., 1994. New evidence for the Holocene sea-level high from the inner shelf, central Great Barrier Reef, Australia. Journal of Sedimentary Research A 64 (4), 881-885.

Carver, G. A., McCalpin, J. P., 1996. Paleoseismology of compressional tectonic environments. In: McCalpin, J.P. (Ed.), Paleoseismology. New York, pp. 183-270 (Chapter 5).

Chappell, J., Polach, H., 1991. Post-glacial sea-level rise from a coral record at Houn Peninsula, Papua New Guinea. Nature 349, 147-149.

Chang, S.C., 1977. The sedimentary-petrological provinces of TainanKaohsiung coastal plain. Petroleum Geology of Taiwan 14, 45-62.

Chao, H. T., 1984. Studies in Coastal Evolution of China. Scientific Technique Publisher, Fujian, 194pp (in Chinese).

Chen, Y. G., 1993. Sea-level change and neotectonics in southern part of Taiwan region since late Pleistocene. Unpublished Ph. D. Dissertation, National Taiwan University (in Chinese, with English abstract).

Chen, Y.G., Liu, T.K., 1996. Sea-level changes in the last several thousand years, Penghu Islands, Taiwan Strait. Quaternary Research 45, 254-262.

Chen, Y.G., Liu, T.K., Tsai, P.S., Wang, C.H., 1994. An Evaluation on Age and Relevant Problems of the Tainan Formation in Tainan area. Special Publication of Central Geological Survey 4, 171-180 (in Chinese, with English abstract).

Fujii, S., Lin, C.C., Tjia, H.D., 1971. Sea-level changes in Asia during the past 11,000 years. Quaternaria 14, 211-216.

Geyh, M.A., Kudrass, H.-R., Streif, H., 1979. Sea-level changes during the late Pleistocene and Holocene in the Strait of Malacca. Nature 278, 441-443.

Gibb, J.G., 1983. Sea-levels during the past 10,000 years B. P. from the New Zealand region - south Pacific Ocean. Abstracts of International Symposium on Coastal Evolution in the Holocene, Japan Society for the Promotion of Science, Tokyo, pp. 28-31.

Gibb, J.G., 1986. A New Zealand regional Holocene eustatic sealevel curve and its applicaton to determination of vertical tectonic movements. The Royal Society of New Zealand Bulletin 24, $377-395$. 
Gong, Z.S., Li, S.T., Xie, T.J., Zhang, Q.M., Xu, S.C., Xia, K.Y., Yang, J.M., Sun, Y.C., Liu, L.H., 1997. Continental Margin Basin Analysis and Hydrocarbon Accumulation of the Northern South China Sea. Science Press, Beijing, China, 510pp.

Hashimoto, W., 1972. Problems on the Tainan Formation and related formations, brought about C-14 dating. Acta Geologica Taiwanica $15,51-62$.

Ho, C. S., 1982. Tectonic Evolution of Taiwan. Ministry of Economic Affairs, Taipei, Taiwan, ROC, 126pp.

Hsieh, S.H., 1972. Subsurface geology and gravity anomalies of Tainan and Chungchou structures of the coastal plain of southwestern Taiwan. Petroleum Geology of Taiwan 10, 323-338.

Huang, Z.G., Li, P.G., Zhang, Z.G., Zong, Y.Q., 1987. Sea-level changes along the coastal area of south China since late Pleistocene. In: Qin, Y.S., Zhao, S.L. (Eds.), Late Quaternary Sea-level Changes. China Ocean Press, pp. 142-154.

Katili, J.A., Tjia, H.D., 1969. Outline of Quaternary tectonics of Indonesia. Bulletin of the National Institute of Geology and Mining Bandung 2 (1), 1-12.

Kern, J.P., 1977. Origin and history of upper Pleistocene marine terraces. San Diego, California. Geological Society of America Bulletin 88, 1553-1566.

Lajoie, K.R., 1986. Coastal tectonics. In: Wallace, R.E. (Ed.), Panel Chairman, National Academy of Sciences, Active Tectonics. National Academy Press, Washington, DC.

Larcombe, P., Carter, R.M., Dye, J., Gagan, M.K., Johnson, D.P., 1995. New evidence for episodic post-glacial sea-level rise, central Great Barrier Reef, Australia. Marine Geology 127, 1-44.

Lin, C.C., 1969. Holocene geology of Taiwan. Acta Geologica Taiwanica 13, 83-126.

Lin, C.C., 1971. Quaternary geology of Tainan area. Mining Research and Service Organization Report 112, 1-26 (in Chinese).

Liu, C.S., Huang, I.L., Teng, L.S., 1997. Structural features off southwestern Taiwan. Marine Geology 137, 305-319.

Lundberg, N., Reed, D. L., Liu, C. S., 1991. The submarine propagation tip of the Taiwan collision: shallow crustal structure and orogenic sedimentation. TAICRUST Workshop Proceedings, National Taiwan University, Taipei, Taiwan, ROC pp. 93-102.

Loeblich, Jr., A.R., and Tappan, H., 1964. Sarcodina chiefly "thecamoebians" and Foraminiferida. In: Moore, R. C., (Ed.), Treatise on Invertibrate Paleontology. Geological Society of America, New York, Part. C, Vol.1-2, 900pp.

Maeda, Y., Miyata, T., Rodda, P., Sugimura, A., Masumoto, E., Matsushima, Y., 1986. Holocene sea-level changes in Viti Levu and Vanua Levu, Fiji. In: Sugimura, A. (Ed.), Sea-level Changes and Tectonics in the Middle Pacific: Report of the HIPAC Project in 1984 and 1985. Kobe University, Kobe, Japan, pp. 137-185.

McCalpin, J.P., 1996. Application of paleoseismic data to seismic hazard assessment and neotectonic research. In: McCalpin, J.P. (Ed.), Paleoseismology. Academic Press, New York, pp. 439-493 (Chapter 9).

Murry, J. W., 1973. Distribution and Ecology of Living Benthic Forminiferids. Heinemann, London, 274pp.

Nakada, M., 1986. Holocene sea-levels in oceanic islands: implications for the rheological structure of the Earth's mantle. Tectonophysics 121, 263-276.

Nelson, A.R., Manley, W.F., 1992. Holocene coseismic and aseismic uplift of Isla Mocha, south-central Chile. Quaternary International 15/16, 61-76.

Nunn, P.D., 1990. Coastal processes and landforms of Fiji: their bearing on Holocene sea-level changes in the south and west Pacific. Journal of Coastal Research 6 (2), 281-310.

Orford, J., 1987. Coastal processes; the coastal response to sea-level variations. In: Devoy, R.J.N. (Ed.), Sea-surface Studies: A Global View. Croom Helm, London, pp. 415-463.
Ota, Y., 1986. Marine terraces as reference surfaces in late Quaternary tectonics studies: examples from the Pacific rim. The Royal Society of New Zealand Bulletin 24, 357-375.

Ota, Y., Machida, H., 1987. Quaternary sea-level changes in Japan. In: Tooley, M.J., Shennan, I. (Eds.), Sea-level Changes. Basil Blackwell, London, pp. 182-224.

Page, B.M., Suppe, J., 1981. The Pliocene Lichi Melange of Taiwan: its plate tectonic and olistostromal origin. American Journal of Science 281, 193-277.

Pirazzoli, P.A., Montaggioni, L.F., 1988. Holocene sea-level change in French Polynesia. Paleogeography Paleoclimatology Plaeoecology 68, 153-175.

Pirazzoli, P.A., Delibrias, G., Montaggioni, L.F., Saliege, J.F., Vergnaud-Grazzini, C., 1987. Vitesse de croissance laterale des platiers et evollution morphologique recente de l'atoll de Reao, iles Taumotu, Polynesie Francaise. Annales de l'Institut Oceanographique (Monaco) 63 (1), 57-68.

Rich, J.L., 1934. Mechanics of low-angle overthrust faulting as illustrated by Cumberland Thrust Block, Virginia, Kentucky and Tennessee. American Association Petroleum Geology Bulletin 19, 1584-1596.

Steckler, M.S., Watts, A.B., 1978. Subsidence of the Atlantic-type continental margins off New York. Earth and Planetary Science Letters 41, 1-13.

Steckler, M.S., Watts, A.B., 1982. Subsidence history and tectonic evolution of Atlantic-type continental margins. In: Scrutton, R.A. (Ed.), Dynamics of Passive Margins, Geodynamics Series 6. American Geophysical Union, Washington, DC, pp. 184-193.

Stuiver, M., Reimer, P.L., 1993. Extended ${ }^{14} \mathrm{C}$ data base and revised CALIB 3.0 ${ }^{14} \mathrm{C}$ age calibration program. Radiocarbon 35 (1), 215-230.

Suggate, R.P., 1968. Post-glacial sea-levels in the Christchurch Metropolitan area. Geologie en Mijinbouw 47, 291-297.

Sugimura, A., Maeda, Y., Matsushima, Y., Rodda, P., Matsumoto, E., 1988. Lobau lowland, Viti Levu, Fiji. In: Sea-level changes and tectonics in the Middle Pacific, report of the HIPAC project in 1986 and 1987. Department of Geography, University of Tokyo, pp. 59-65.

Sun, S.C., 1964. Photogeologic study of the Tainan-Kaohsiung coastal plain area. Taiwan. Petroleum Geology of Taiwan 3, 39-51.

Suppe, J., 1981. Mechanics of mountain building and metamorphism in Taiwan. Memoir of Geological Societh of China 4, 67-89.

Suppe, J., 1983. Geometry and kinematics of fault-bend folding. American Journal of Science 283, 684-721.

Thom, B.G., 1983. Relative sea-levels in southeast Australia in the Holocene. Abstracts of International Symposium on Coastal Evolution in the Holocene. Japan Society for the Promotion of Science, Tokyo, pp. 28-31.

Teng, L.S., 1990. Geotectonic evolution of late Cenozoic arc - continent collision in Taiwan. Tectonophysics 183, 57-76.

Tooley, M.J., 1987. Sea-level studies. In: Tooley, M.J., Shennan, I. (Eds.), Sea-level Changes. Basil Blackwell, Oxford and New York, pp. 1-24.

Woods, A.J., 1980. Geomorphology, deformation and chronology of marine terraces along the Pacific coast of central Baja California, Mexico. Quaternary Research 13, 346-364.

Wu, T.J., 1990. ${ }^{14} \mathrm{C}$ dating and neotectonic implications of the Tainan Formation on Tainan Tableland. Master Thesis, Department of Geology, National Taiwan University (in Chinese).

Wu, T.J., Chen, Y.G., Liu, T.K., 1992. Sedimentary history and neotectonic implication of Tainan formation on Tainan Tableland. TiChih 12 (2), 167-184 (in Chinese, with English abstract).

Yeats, R.S., 1986. Faults related to folding with examples from New Zealand. The Royal Society New Zealand Bulletin 24, 273-292.

Yen, H.Y., Lian, W.T., Kuo, B.Y., Yeh, Y.H., Liu, C.S., Reed, D., Lundberg, N., Su, F.C., Chung, H.S., 1995. A regional gravity map for the subduction-collision zone near Taiwan. Terrestrial, Atmospheric and Oceanic Sciences 6 (2), 233-250. 